\title{
A Marketing Approach To Service Quality In Accounting: A Case Study
}

Erwin Waldmann, (Email: erwin.waldmann@buseco.monash.edu.au), Monash University Janek Ratnatunga, (Email: janek.ratnatunga@buseco.monash.edu.au), University of Richmond

\begin{abstract}
Accounting firms operate in a competitive marketplace, consequently the quality imperatives and philosophies that currently apply to manufacturing are also relevant to service industries like professional accounting services. This begs the question of how quality should be defined and what pedagogy should be used for achieving the goal of continuous quality improvement. The service quality concepts are of particular relevance to management accounting due to its involvement in quality assurance in manufacturing. This paper looks at some of the research and methodologies developed by Marketing Science that takes a customer perceptive in defining and measuring service quality, and applies one such methodology, SERVPERF, to a firm in the Accounting and Management Consulting industry. In this study, data representing customer service quality (performance) perceptions and satisfaction with the services provided by the firm has been used to identify areas needing improvement. The study also identifies those areas in which the firm is effective in providing services. The results of this analysis appear to provide some support for conceptualising and measuring service quality as an attitude as suggested by Cronin and Taylor (1992).
\end{abstract}

\subsection{Introduction}

ervice Industries have for some time, been investigating and implementing quality improvement methods developed in the manufacturing industries to improve efficiency and service quality (Motwani, et. al. 1996). The aim of this paper is to take a customer perspective (broadly defined) to the question of quality in accounting and management consultancy services, and adapt a range of methodologies developed in Marketing Research to identify service quality problems and the processes necessary to rectify such problems.

In the last few decades, the shift, from manufacturing to service, which accelerated in the 1980s and continues into the 2000s has made service the primary growth segment of most Western economies. The notion of service quality has become increasingly important with increasing competition, and service quality has been identified as a determinant of market share, return on investment and cost reduction (Anderson and Zeithaml 1984; Parasuraman et. al. 1985). In fact, Devlin and Dong (1994) note that in an increasingly competitive environment, service quality linked to customer satisfaction leads to greater market share and profits.

Service organizations provide essentially two forms of quality: technical quality and functional quality (Gronroos 1984). The first, technical quality, is the degree to which the industry is able to do things "right" as measured against some technical "industry standard." However, in service sectors, knowledge of the technical quality of services remains largely the domain of service professionals (Bopp 1990). For example, few individuals understand the technical aspects of the Accounting and Management Consulting industry, with all its tools, techniques, accounting standards, tax laws and the like.

$\overline{\text { Readers with comments }}$ or questions are encouraged to contact the authors via email. 
Thus it is the second aspect of quality, functional quality, which refers to the manner in which services are delivered to customers that is more understood by the customers, and this forms their perceptions of service quality (see Babakus and Mangold 1992, Donabedian 1980 and 1982).

The definition of quality in accounting services would receive numerous responses depending on the perspective of the person asked. Several researchers have, in fact, sought to define and measure the concept of service quality (see Carman 1990; Cronin and Taylor 1992; Parasuraman et. al. 1985; 1988; and 1991; and Teas 1993). Parasuraman et. al. (1985) state that service quality is more difficult to define and measure than product quality because services are intangible, heterogenous (i.e. service quality can vary by customer, day or producer), and production is inseparable from consumption.

As this paper will focus on the expectations of end users, quality will be defined as "the ability of a product or service to meet customers' needs and reasonable expectations" (Berry 1986). If the service is provided by an outside firm then customers are easily identified and comprise all clients seeking service. However if the accounting service is being provided in-house (for example management accounting services within a corporation) then the question of "who are our customers" requires analysis. The identification of customers and the development of customer profiles is a critical part of any quality evaluation. It is quite possible that management accounting information is provided to a wider range of people than is presently perceived by the providers of this service, i.e. the management accountant.

Problems in customer service deserve particular attention if an accounting firm or an accounting function within an organisation is to prosper in an increasingly competitive market. Therefore, even in an organisational setting, the provision of management accounting information is becoming increasingly competitive, with other information professionals such as industrial engineers and IT specialist vying for leadership in this role. Information relating to customer service problems needs to be gathered and satisfactorily addressed in a timely manner. This will encourage positive word-of-mouth and a customer-orientated image. Research has also shown that if timely and compensatory action is taken with service faults, the individual will attach less importance to the annoyance, and experience satisfaction, which is positive for the organisation (Bitner et. al. 1990).

A customer's perception of a firm's or department's service quality will be determined by previous encounters. As a result, customer expectations towards different types of services provided will be influenced by past experiences, particularly if inconvenience and trouble was experienced (Brandt and Reffett 1989). Timely and accurate information on customer problems indicates whether, and to what extent, targeted quality standards are met. It allows for variance analysis and remedial action to be taken to prevent future occurrence of the problem.

The concept of Total Quality Management (TQM) is well known. However, although there is a strong call for "Customer First" in TQM, questions of perceived service quality or satisfaction measurement are not discussed very intensively. When dealing with a pure service provider like an accounting firm or in-house accounting department, the problem is magnified. Service to customers is only one aspect of a manufacturing environment; to a pure service provider it is the only aspect. One method of overcoming this problem with service quality is to connect quality methodology to the research and methods developed by Marketing Science. This paper will apply this methodology to the measurement of service quality in accounting services. Methods of measuring perceived service quality will be discussed and evaluated. This will then be combined with the internal process of problem solution development and problem avoidance. To provide an applied aspect, two comparative case studies utilising the above methodology will be overviewed, and the finding of a single-site case study of the application of one of the methodologies, SERVPERF, will be presented.

In terms of the previous casework that has been done in the service sector with regards to quality, the literature is quite substantial. Recent work has been done in health care (Badrick et. al. 1997) and retailing (Sohal and $\mathrm{Lu} \mathrm{1998).} \mathrm{Quality} \mathrm{attributes} \mathrm{have} \mathrm{also} \mathrm{been} \mathrm{reviewed} \mathrm{in} \mathrm{terms} \mathrm{of} \mathrm{customer} \mathrm{services} \mathrm{(Hall} \mathrm{1997);} \mathrm{financial}$ services (Knights and McCabe 1996); construction (Pheng and Ke-Wei 1996) and catering services (Chang et. al. 1997). 
Many of the above cases were single-site cases from which generalisations were drawn. The author considered it acceptable, therefore, to conduct a single-site case study in the Accounting and Management Consulting environment.

\subsection{The Detection Of Service Quality Problems}

To ensure long-term customer satisfaction an organisation needs to identify all service problem areas (Denton 1990). There are a number of survey methods that draws on marketing literature and include a range of both informal and standardised multi-attribute tools. These include three "incident-oriented" measurements known as Complaint Analysis, Critical Incident Technique, and Sequential Incident Technique, and two models, one known as SERVQUAL, which employs a "gaps" approach (see Parasuraman et. al. 1985), and the other known as SERVPERF which employs an alternative "performance-based" service quality measurement (see Cronin and Taylor 1992).

\subsection{Complaints Analysis}

The first of the incident orientation methods reviewed is Complaints Analysis. Complaints to an accounting firm or an in-house management accounting department would come from a wide range of customers. A systematic procedure would need to be implemented with guidelines on when and how these complaints are to be recorded. This will provide a low cost method of acquiring relevant quality information for future analysis. This measure assumes that the complaint must have been significantly important to the customer for them to go to the trouble of making it in the first place. An analytical dissection of the content of these complaints over a period of time can provide an extremely valuable tool for the identification of weaknesses and also possible opportunities. Though useful, this method has its limitations. By their very nature the information in these complaints cannot be regarded as representative either in range or content, mainly because only a fraction of dissatisfied customers usually complain, and even in such cases only a limited range of faults are reported.

\subsection{Critical Incident Technique}

While complaint analysis attempts to evaluate quality problems made by customers, the Critical Incident Technique (CIT) takes a proactive approach to the systematic investigation of customer experiences. The value of this approach has been demonstrated in service industries such as hotels, car care establishments and airlines (Stauss 1993). "Critical incidents" are those which customers perceive as being unusually positive or negative. The CIT approach can be part of a more general one-on-one depth interview used to elicit customer perceptions. During the course of this interview survey, customers will be encouraged to recall and evaluate these perceived critical experiences (both positive and negative) in depth.

\subsection{Sequential Incident Method}

The Sequential Incident Method is a combination of flowcharting (blueprinting) and in-depth interviewing. It represents a combination of information gained from customer interviews and a flow chart of service production (Stauss 1993). The flow chart (or blueprint) will represent all service activities and their interdependences enabling any service problem to be traced to the relevant activity (Kingman-Brundage 1989). Identifying problems through the Sequential Incident Method would enable an accounting firm to comprehensively analyse service problems.

To determine severity of the problem some quantifiable method needs to be used. In the case of multiattribute measurements, the extent of the gaps between expectations and perceptions can be taken as a problem indicator (Behara and Lemmink 1991). Responses to the questions can be quantified and analysed. With incident orientation methods like Critical Incident Technique, interviews should have a basic structure with checklists of problem categories. A Likert scale can be used to determine intensity and responses recorded for future analysis. With complaint analysis, the frequency of complaints per problem category gives a reasonable indication of its importance, and the urgency of a solution. 
To enable a firm or department to implement a philosophy of continuous quality improvement these surveys will have to be ongoing. This will formalise a review and implication process allowing for trends to be identified and previous corrective actions evaluated. A combination of the above techniques best suited to aims and resources would have to be chosen.

\subsection{The SERVQUAL Model}

One of the critical problems in evaluating quality in a service product like accounting is the measurement of difference between expected and actual service standards. With physical products this measurement is relatively straightforward. The same cannot be said with an intangible service like accounting. One solution is to use the "gaps" approach derived from marketing literature (Beach and Burns 1995; Stauss 1993). Much of the initial work in developing a model to define and assess service quality has been conducted by Parasuraman, Zeithaml, and Berry (1985). In conceptualising the basic service quality model Parasuraman et.al. (1985) identified ten key determinants of service quality as perceived by the company and the consumer: reliability, responsiveness, competence, access, courtesy, communication, credibility, security, understanding/knowing the customer and tangibility (they reduced these to five key determinants in their 1988 paper). Thus, in this model, the quality differential is not determined by looking at 'objective' quality but in 'perceived' quality, i.e. the customer's judgement about an entity's overall excellence or superiority. The methodology is thus based on a comparison of the gap between expectations and perceived performance. Expectations have a very precise meaning for Parasuraman et. al. (1985, 1988, and 1990) who are the developers of the SERVQUAL model. They are not viewed as predictions of what is likely to happen, but as desires or wants of consumers. Findings by Parasuraman et. al. (1990) showed that clients judge service quality by using the same general criteria, irrespective of the type of service investigated.

Parasuraman et.al. (1985) noted that discrepancies existed between the firm's and the customer's perceptions of the service quality delivered. In investigating these discrepancies, they found that service quality can be assessed by measuring the discrepancies or "gaps" between what the customer expects and what the consumer perceives he or she receives. They argued that the magnitude, and direction of this gap, directly affected the service quality that the consumer perceives, Parasuraman et.al. (1985) noted that customers would have perceptions of high service quality to the extent that their expectations are lower than the perceived service performance. If the converse were true, customers would perceive low service quality.

Parasuraman et.al. (1985) assert that their framework can be used for identifying differences in the quality of goods and services by distinguishing between the properties of a good or service. They note that Nelson (1974) defined "search properties" as properties that can be determined before purchasing (such as credibility and tangibles), and "experience properties" as properties that can be determined only after purchase or consumption. Further, Darby and Karni (1973) defined "credence properties", (such as competence and security) as properties or characteristics that consumers often find extremely difficult to evaluate after their purchase. Therefore, Parasuraman et.al. (1985) concluded that consumers typically rely on experience properties when evaluating service quality.

Based on their review of the literature, Parasuraman et.al. (1985) developed the SERVQUAL scale that was designed to uncover broad areas of good or bad service quality and can be used to show service quality trends over time, especially when used with other service quality techniques.

The SERVQUAL scale is based on a difference score between customer expectations of service and their perceptions after receiving the service. Parasuraman et.al. (1988) isolate five dimensions of service quality ranked in order of importance as follows:

- $\quad$ Reliability: Ability to perform the promised service dependably and accurately.

- $\quad$ Assurance: Knowledge and courtesy of employees and their ability to inspire trust and confidence.

- $\quad$ Tangibles: Physical facilities, equipment, and appearance of personnel.

- $\quad$ Responsiveness: Willingness to help customers and provide prompt service.

- $\quad$ Empathy: Caring, individualised attention the firm provides its customers. 
The question items in each of these dimensions are designed to be easily edited for use in different service industries. Consequently the instrument would comfortably lend itself to accounting service quality evaluation.

Parasuraman et.al. (1991) assert that the SERVQUAL scale deals with perceived quality and looks specifically at service quality, not customer satisfaction. They state, "perceived service quality is a global judgement or attitude concerning the superiority of service whereas satisfaction is related to a specific transaction" (p. 16). In the final SERVQUAL scale (Parasuraman et.al. 1991) service quality is measured using a 22 -item questionnaire (with a seven-point Likert scale bounded by "strongly agree" and "strongly disagree") designed to load on to the five key dimensions listed above (see Table 1). Each item is used twice: first, to determine customer's expectations within the service category being investigated and second, to measure perceptions of performance. Their own empirical evidence indicates that the scale has a reliability of between .80 and .93 , good trait validity and predictive/concurrent validity (Parasuraman et.al. 1991).

Teas (1993) questions SERVQUAL's discriminant validity. He notes that the service quality expectations concept may have serious discriminant validity shortcomings that can cause the "perceptions-minus-expectations" service quality measurement framework to be "a potentially misleading indicator of customer perceptions of service quality" (p.33). He notes that SERVQUAL's lack of discriminant validity results in a significant part of the variance in its expectations scores being determined by the respondent's "misinterpretations" of the expectation questions.

Churchill et. al. (1993) argue that because the SERVQUAL scales "scores" are really difference scores (perception scores minus expectation scores), problems of reliability, discriminant validity, and variance restrictions exist. They showed that while SERVQUAL had high reliability, a non-difference score rated higher in reliability. Their findings also showed that the scale "failed to achieve discriminant validity from its components", and the distribution of the SERVQUAL scores were non-normal.

\subsection{The SERVPERF Model}

As indicated above, there have been many studies that have failed to replicate SERVQUAL's five distinct dimensions and validity. Perhaps the most intense criticism of the SERVQUAL scale has come from Cronin and Taylor (1992), who have developed an alternative "performance-based" service quality measurement scale called SERVPERF.

Cronin and Taylor (1992) base their scale on an earlier work by Bolton and Drew (1991) who noted that a customer's perception of service quality is based on his or her "preconceived" attitude about the service. They argue that a consumer's current attitude is based on their residual attitude from a previous period about the service quality and their satisfaction or dissatisfaction with the service. As consumers experience a service, their attitudes about the service quality may be revised, thereby causing a change in future attitudes.

According to Cronin and Taylor (1992), their unweighted performance-based SERVPERF scale was a better method of measuring service quality. They claim that this scale's reliability ranges between .884 and .964 , depending on industry type, and exhibits both convergent and discriminant validity.

The SERVQUAL versus SERVPERF debate is ongoing with both groups of researchers (and others) presenting further arguments to support their favoured perspective. For example, Parasuraman et.al. (1994) assert that their research shows that SERVQUAL's convergent and discriminant validity is as good or better than SERVPERF's validity, and that there is significant theoretical and empirical research to support their P-E gap theory, while Cronin and Taylor (1994) assert that the real question that should be asked is whether (or not) their model can produce a valid and reliable measure of service quality; insisting that, based on their research, their SERVPERF scale can provide a more reliable, valid, and useful tool for measuring overall service quality levels or attitudes than the rival SERVQUAL model. 
Most recent articles have supported Cronin and Taylor's (1992) performance-based paradigm over Parasuraman et. al.'s (1985) disconfirmation-based paradigm (see Oliver 1993; Babakus and Boller 1992; and Babakus and Mangold 1992). One of the most telling reviews is provided by Boulding et. al. (1993) who state that "our results are incompatible with both the one-dimensional view of expectations and the gap formation for service quality. Instead, we find that service quality is directly influenced only by perceptions" p.24.

Although it is possible to advance a relatively strong case for using the SERVQUAL scale, we chose to use the SERVPERF scale in our study primarily because of many criticisms of SERVQUAL (see Cronin and Taylor 1992; Teas 1993; Churchill et. al. 1993), and the failure of empirical studies to replicate SERVQUAL's initial success (see Carman 1990; Babakus and Boller 1992). In the case of SERVPERF, research in importanceperformance analysis has been conducted in such areas of marketing as health care (Hawes and Rao 1985), educational services (Hawes and Glisan 1983), housing (Hawes et. al. 1982), automotive (Martilla and James 1977), and food (Sethna 1982) and its use in service quality research has been suggested by Cronin and Taylor (1994). However, while preferring to use SERVPERF, we are mindful that although Cronin and Taylor (1992) have argued strongly in defense of SERVPERF, the scale has yet to be empirically tested in as wide a number of industries as has SERVQUAL.

\subsection{Comparative Cases}

While researchers have looked at a variety of service industries, there is yet to be any published service quality information on the Accounting and Management Consulting industry. There are no case studies in management accounting at present, that cover the use of SERVQUAL or SERVPERF, nor, the other Marketing tools described in this manuscript. However research has recently been done on the legal profession (Witt and Stewart 1996) and Management Information Systems (Kettinger and Lee 1997). Comparisons can be drawn between these cases and management accounting (and accounting generally). The cases involve the provision of information services to customers, and the information is of a technical nature prepared by trained professionals.

Quality of service in any profession is a vital ingredient in the retention of existing clients, and the acquisition of new clients. Furthermore 'bad quality' is expensive. Doing things wrong, having to repeat work, checking and rechecking costs time and money. Customers want services that meet their requirements and expectations (Witt and Stewart 1996). It is of interest therefore to overview the major findings in these comparative cases.

The most important service quality dimension found in these cases was communication, followed by reliability and competence. The importance of communication may be explained by the fact that there is likely to be a significant knowledge gap between a customer and professional service provider. Customers rely on this advice and expect the best possible information and guidance. Specific communication problems identified included:

- $\quad$ The professional should speak to the client in language which they can understand.

- The customer should feel comfortable in asking questions, if they do not understand any aspect of a matter.

- $\quad$ Written communication and reports should be easily understandable.

- $\quad$ The professional should ensure that the customer understands the meaning and relevance of all documents and reports provided (i.e. it is not the customers responsibility to be able to understand the information).

An interesting finding has been that, the customer usually does not have the knowledge base to be able to judge how well the professional has performed. They consequently rely on the various impressions gained during their dealings with the professional to evaluate the quality of the service. These impressions can be based on a range of factors including attention paid to the client, and concern for their problems; the level of computer technology employed; service quality of support staff (especially first contact personal such as receptionists) and general physical facilities. These factors can offer numerous marketing opportunities to service firms that have a high degree of client contact. 
Other salient points discovered in these cases include:

- $\quad$ Only relevant reports and information should be sent.

- $\quad$ Timeliness of information should be determined by the client.

- $\quad$ Reliability and competence were seen as key requirements by the client.

- The professional should organise what steps need to be taken in the future and should liaise closely with the client.

- A professional should admit if certain areas are outside their area of expertise and be prepared to seek expert advice on those subjects as soon as the need arises.

- $\quad$ Documents and reports should be well produced and presented.

\subsection{Research Study}

We studied a firm in the Accounting and Management Consulting industry in Australia. This firm generates revenues primarily from advice given to large and small businesses, individuals and families. Sources of revenues include the sale of a variety of accounting, consulting and financial services including: bookkeeping; company secretarial work; information technology consulting; management accounting projects such as the installation of Activity Based Costing systems and the Balanced Scorecard; cash flow analysis, budgeting and stock control for SMEs; company valuations; GST compliance; and tax planning and compliance. The Accounting and Management Consulting industry is very competitive and is comprised of a large number of small suburban practices and seven major "national" firms and five international "Big Five" firms.

The objectives of this study are as follows:

- $\quad$ Report the results of a study that examines the usefulness of the SERVPERF scale for assessing customer perceptions of service quality in the Accounting and Management Consulting industry.

- Assess the reliability of service quality measures as it applies to the Accounting and Management Consulting industry.

- Identify the dimensions of service quality that are important to customers of Accounting and Management Consulting Professional Practices.

- $\quad$ Assess the overall service quality and satisfaction level as perceived by customers of Accounting and Management Consulting Professional Practices.

\subsection{Method}

The study was conducted with the co-operation of a large suburban Accounting and Management Consulting practice in Victoria, Australia. The target population was defined as the clients (individuals and firms) that obtained Accounting and Management Consulting and related services. The SERVPERF survey instrument (Cronin and Taylor 1992) was mailed to a systematic random sample of 1000 clients who had obtained Accounting and Management Consulting advice from the company in the last three years.

Along with the SERVPERF (performance and expectation) items, the survey instrument contained questions related to the attribute importance and the demographic characteristics of the firm and the respondent. Additionally, three questions were inserted to gather information on customer satisfaction, an overall rating of service quality, and intentions to use the current service in the future. Besides the questionnaire, each mailing packet included a covering letter, requesting customer responses to questions about the quality of the services, and a self-addressed, postagepaid, envelope. The co-operating company provided a single set of mailing labels.

\subsection{Response Rate}

The 1000 surveys were mailed on in June, 2000. The postal service returned 87 questionnaires because of address problems. Of the remaining 913 questionnaires, 176 completed questionnaires were returned, yielding an overall response rate of 19.27 percent. This response rate is not inconsistent with previous studies (Amsden 1989; 
Babakus and Boller 1992; Babakus and Mangold 1992). Each completed questionnaire was examined for completeness, coded and used in the data analysis phase of the study. While a second mailing would have improved the response rate, the management of the co-operating firm believed that the respondents were reflective of the population of clients. Therefore, no follow-up attempts were made. The response rate was also thought to be adequate for scale development and testing purposes (Press and Ganey 1989).

Using the technique suggested by Armstrong and Overton (1977), and used by Babakus and Boller (1992), t-tests were used to compare the responses of the "early" respondents (first 10 days after mailing) and "late" respondents (all remaining). The analysis revealed that there were no significant differences between the groups. Therefore, nonresponse bias was not expected to be a major problem.

\subsection{Data Analysis And Results}

The respondents were from wide variety of backgrounds. Eighty-two percent or 144 of the 176 respondents indicated that they were exclusive users of the Accounting and Management Consulting services provided by the cooperating company. Seventy four percent of the respondents were individual clients, 19 percent were small firms, 4 percent were very large firms that used mainly management accounting services, and 3 percent did not respond to the question.

Based on the findings presented by Cronin and Taylor (1992), performance was used as a measure of service quality. As suggested in the literature (see Anderson and Gerbing 1988; Bagozzi and Yi 1988; Churchill 1979), scale reliability, dimensionality, and validity were conducted to determine the adequacy of using the SERVPERF scale to assess customer perception of Accounting and Management Consulting services.

In this study, Cronbach coefficient alpha was used to assess the internal consistency of SERVPERF. Dimensionality and validity assessment were assessed using factor and correlation analyses.

\subsection{Reliability And Validity}

In arguing for a performance-based measure of service quality, Cronin and Taylor (1992) asserts that service quality is best measured as an attitude. Following the method used by Cronin and Taylor (1992), the 22 scale items (performance) were treated as unidimensional and a factor analysis was performed using the procedure in SPSSX. As expected, all the items loaded on a single factor. The reliability, as assessed by coefficient alpha, was .961 , further indication that the scale can be treated as unidimentional. Therefore, the items were summed and used in the analysis.

\subsection{Importance-Performance Perceptions}

Since respondents rated both the importance and the performance of the various items, it is possible to ascertain the degree of association between the two sets of items.

Table 1 presents the means of both the importance and performance ratings. Respondents indicated relatively high levels in importance and performance. The relatively high levels of importance reported were in keeping with previous research, which suggests that the 22 items are the relevant services marketing attributes. The relatively high performance or service quality ratings, on the individual items, are in keeping with the reported high level of overall satisfaction $($ mean $=5.303)$.

Examination of the individual items reveal that in general, performance ratings were lower than importance ratings, indication that there is some room for improving service quality. "Providing services at times promised", "performing right the first time", "prompt service", "doing as promised" and "having trustworthy employees" were among the most critically important attributes. It is interesting to note that none of the attributes had a mean importance rating which was below 5.0. The lower importance ratings on "up-to-date financial products and services", "appealing facilities and equipment", and having "visually appealing printed materials and reports", may 
be due to the nature of the Accounting and Management Consulting service. In the Accounting and Management Consulting industry, customers may have little knowledge of the financial or other analyses that are provided by the accounting firm, as long as the technical or compliance issue is resolved, e.g. in the Corporate Services area, as long as the client has the worry of filing annual returns on time removed by the Accountant, the visual aspect of the service (like a well bound Annual Return Report) seems to be of less importance. This was somewhat contrary to the findings of the two comparative cases overviewed earlier.

The mean performance ratings are not provided in rank order, but an examination of Table 2 reveals that all attributes had mean values of 5.30 or more on a seven-point scale. "Courteousness to clients", "professional looking accountants", "clients feeling safe in business dealings", "willingness to help clients", "prompt service to clients", and "personal assistance to clients", were the six highest ranked performance attributes. Interestingly, the highest ranked importance attributes were not the highest ranked performance items.

Figure 1 represents the plotting of the means of the importance and performance attributes. All 22 attributes were included in the top right hand quadrant of the importance-performance graph. This suggests that the Accounting and Management Consulting firm needs to continue the good work of supplying quality service to the clients. Maintaining current client services practices would be recommended for these 22 attributes.

As indicated by Hawes and Rao (1985), the diagonal represents points where the importance and performance ratings are equal (Figure 1). Items above the diagonal have importance ratings that are greater than the performance rating. Consequently, clients would not be fully satisfied with items that are above the rating line, an indication of what the firm could do to improve performance and perceived client satisfaction. Indeed, attributes above the rating diagonal line represent market opportunities for firms that could do a better job.

In this study, 18 of the 22 items fell above the diagonal. These items represent "market opportunities". Therefore the firm should adopt strategies to improve service quality performance in these areas. In this respect, items furthest from the diagonal line, such as "performance service right the first time", offers an attractive market opportunity if the firm can improve perceptions of its performance in providing this aspect of the service. The firm can significantly improve customer perceptions of its service quality by paying particular attention to the items above the diagonal.

Attributes below the diagonal line have performance ratings higher than the corresponding importance ratings. These indicate little or no customer dissatisfaction. These items represent "satiated needs" and the marketer would find it difficult to gain a competitive edge by stressing these attributes.

In this study, one item ("visually appealing printed materials and reports") fell on the diagonal, and 3 items fell just below the diagonal ("up-to-date financial products and services", appealing physical facilities" and "professional looking accountants"). While highly satisfied, the marketer needs to note that customers may be using the "professional looking accountant" attribute as a surrogate for other more important attributes such as "up-to-date financial products and services", and "appealing physical facilities".

\subsection{Quality Perceptions, Satisfaction and Purchase Intentions}

Correlation analysis was used to determine the relationship between quality perceptions (performance), satisfaction, and purchase intentions (Table 3).

Customer satisfaction and purchase intentions were determined by asking respondents to rate the degree of satisfaction and the frequency with which they are likely to use the firm for further Accounting and Management

Consulting in the future. Service quality was measured using a global measure and also using the multi item SERVPERF scale. Results of the correlation indicate that SERVPERF is highly and significantly related (.7147) to customer satisfaction. 
The indications from Table 3 are, therefore, that high service quality leads to high customer satisfaction but not necessarily to purchase intentions. Indeed, service quality does not appear to be directly and significantly related to purchase intentions. These findings are consistent with those reported by Cronin and Taylor (1992).

The strength of this relationship is confirmed by the relatively high correlation (.8022) between satisfaction and service quality as measured by a single item. Further, customer satisfaction seems to be more directly related to purchase intentions than either SERVPERF or the single item service quality measure.

\subsection{Conclusion}

Concepts like Total Quality Management have existed in manufacturing industries for some time. Recently moves have been made to apply this quality philosophy to service industries as well. Accounting services fall within this category. Of particular interest would be management accounting due to its expertise in applying quality methodology in manufacturing. It beholds the profession to apply these quality standards and philosophies to itself. Accountants should provide customers with the confidence that they possess all the quality characteristics that the customer considers important, and that these characteristics are at or above the standards expected.

In this study, the SERVPERF scale was found to explain a great deal of the variation in the service quality of an Accounting and Management Consulting Firm. While satisfaction seems to have a significant positive effect on purchase intention, service quality does not seem to have a similar effect. Indeed, satisfaction seems to be more closely tied to purchase intentions than is service quality. The performance items in the SERVPERF instrument showed evidence of unidimentionality and strong internal consistency.

Since SERVPERF essentially measures performance, it can be used in conjunction with attribute importance to determine consumer attitudes toward key service attributes. The importance attributes represent the consumer's evaluative criteria in service choice. This, in turn, can be used in determining the firm's marketing strategy.

Further research in this area could include empirical studies on how in-house accounting departments of firms define quality and what methodology is used (if any) to measure it. 
TABLE 1 - SERVQUAL Questionnaire

\begin{tabular}{|c|c|c|c|c|c|c|c|c|c|c|c|c|c|c|c|c|c|c|}
\hline \multirow[t]{3}{*}{ With Regard to: } & \multicolumn{9}{|c|}{ My DESIRED service level is: } & \multicolumn{9}{|c|}{$\begin{array}{l}\text { My PERCEPTION of The Firm's service } \\
\text { level is: }\end{array}$} \\
\hline & \multicolumn{5}{|c|}{ Low } & \multicolumn{4}{|c|}{ High } & \multicolumn{5}{|c|}{ Low } & \multicolumn{4}{|c|}{ High } \\
\hline & 1 & 2 & 3 & 4 & 5 & 6 & 7 & 8 & 9 & 1 & 2 & 3 & 4 & 5 & 6 & 7 & 8 & 9 \\
\hline Providing services as promised & & & & & & & & & & & & & & & & & & \\
\hline $\begin{array}{l}\text { 2. Dependability in handling } \\
\text { client's problems }\end{array}$ & & & & & & & & & & & & & & & & & & \\
\hline $\begin{array}{l}\text { 3. Performing services right the } \\
\text { first time }\end{array}$ & & & & & & & & & & & & & & & & & & \\
\hline $\begin{array}{l}\text { 4. Providing the service at the } \\
\text { promised time }\end{array}$ & & & & & & & & & & & & & & & & & & \\
\hline $\begin{array}{l}\text { 5. Keeping clients informed of } \\
\text { when something will be done }\end{array}$ & & & & & & & & & & & & & & & & & & \\
\hline 6. Prompt service to clients & & & & & & & & & & & & & & & & & & \\
\hline 7. Willingness to help clients & & & & & & & & & & & & & & & & & & \\
\hline $\begin{array}{l}\text { 8. Readiness to respond to } \\
\text { clients' requests }\end{array}$ & & & & & & & & & & & & & & & & & & \\
\hline $\begin{array}{l}\text { 9. Personnel who instill } \\
\text { confidence in their clients }\end{array}$ & & & & & & & & & & & & & & & & & & \\
\hline 10. Making clients feel assured & & & & & & & & & & & & & & & & & & \\
\hline $\begin{array}{l}\text { 11. Personnel who are always } \\
\text { courteous and considerate }\end{array}$ & & & & & & & & & & & & & & & & & & \\
\hline $\begin{array}{l}\text { 12. Personnel who have the } \\
\text { expertise to look after clients } \\
\text { needs }\end{array}$ & & & & & & & & & & & & & & & & & & \\
\hline $\begin{array}{l}\text { 13. The individual attention that } \\
\text { clients get }\end{array}$ & & & & & & & & & & & & & & & & & & \\
\hline $\begin{array}{l}\text { 14. Personnel who deal with } \\
\text { clients in a caring fashion }\end{array}$ & & & & & & & & & & & & & & & & & & \\
\hline $\begin{array}{l}\text { 15. Personnel who have the } \\
\text { client's best interest at heart }\end{array}$ & & & & & & & & & & & & & & & & & & \\
\hline $\begin{array}{l}\text { 16. Personnel who understand the } \\
\text { needs of their clients }\end{array}$ & & & & & & & & & & & & & & & & & & \\
\hline $\begin{array}{l}\text { 17. The modern equipment and } \\
\text { apparatus available }\end{array}$ & & & & & & & & & & & & & & & & & & \\
\hline $\begin{array}{l}\text { 18. The visually appealing } \\
\text { facilities }\end{array}$ & & & & & & & & & & & & & & & & & & \\
\hline $\begin{array}{l}\text { 19. Personnel who have a neat, } \\
\text { professional appearance }\end{array}$ & & & & & & & & & & & & & & & & & & \\
\hline $\begin{array}{l}\text { 20. The visually appealing } \\
\text { communication materials } \\
\text { associated with the service }\end{array}$ & & & & & & & & & & & & & & & & & & \\
\hline 21. Convenient office hours & & & & & & & & & & & & & & & & & & \\
\hline $\begin{array}{l}\text { 22. How would you rate the over } \\
\text { Firm? }\end{array}$ & & & & & & & & & & & & & & & & & & \\
\hline
\end{tabular}

Table 1 continued on next page: 
Table 1 continued:

DESIRED LEVEL: the excellence level of service you desire from the personnel of an excellent short-term insurance brokerage (see second column). Please consider the level of service you would desire for each of the statements below. If you think a feature requires a very high level of service quality, choose number 9 in the second column. If you think a feature requires a very low level of service quality choose number 1 in the second column. If your requirements are less extreme, choose an appropriate number in between.

PERCEIVED LEVEL: your perception of the service quality that the firm provides (see third column). Please use the same 9point scale to evaluate the level of service you perceive.

TABLE 2 Importance and Performance Ratings of Service Attributes

\begin{tabular}{|c|c|c|c|}
\hline Att \# & Attribute Description & Mean Imp* Rating & Mean Perf@ Rating \\
\hline 1 & Up-to-date financial products and services & 5.438 & 5.494 \\
\hline 2 & Should do as promised & 6.670 & 5.778 \\
\hline 3 & Should tell when services will be performed & 6.500 & 5.881 \\
\hline 4 & Employees who are trustworthy & 6.670 & 5.938 \\
\hline 5 & Individual attention to clients & 6.182 & 5.659 \\
\hline 6 & Appealing physical facilities and equipment & 5.080 & 5.313 \\
\hline 7 & Interest in solving client problems & 6.188 & 5.864 \\
\hline 8 & Prompt service to clients & 6.716 & 6.017 \\
\hline 9 & Clients feel safe in dealings & 6.540 & 6.045 \\
\hline 10 & Convenient operating hours & 6.256 & 5.875 \\
\hline 11 & Professional looking Accountants & 6.148 & 6.233 \\
\hline 12 & Perform service right the first time & 6.688 & 5.432 \\
\hline 13 & Always willing to help client & 6.625 & 6.051 \\
\hline 14 & Consistently courteous with client & 6.557 & 6.295 \\
\hline 15 & Employees give personal assistance & 6.420 & 5.989 \\
\hline 16 & Visually appealing printed materials and reports & 5.511 & 5.466 \\
\hline 17 & Provide advice at times promised & 6.733 & 5.932 \\
\hline 18 & Never too busy to respond to request & 6.477 & 5.943 \\
\hline 19 & Knowledgeable and Technically competent & 6.528 & 5.864 \\
\hline 20 & Have client's best interest at heart & 6.455 & 5.608 \\
\hline 21 & Insist on error free records & 6.455 & 5.483 \\
\hline 22 & Understand client's specific needs & 6.239 & 5.795 \\
\hline \multicolumn{4}{|c|}{ * Ratings were collected on a seven-point Likert scale ranging from $1=$ very unimportant to $7=$ very important } \\
\hline
\end{tabular}


FIGURE ONE: Importance-Performance Co-Relations

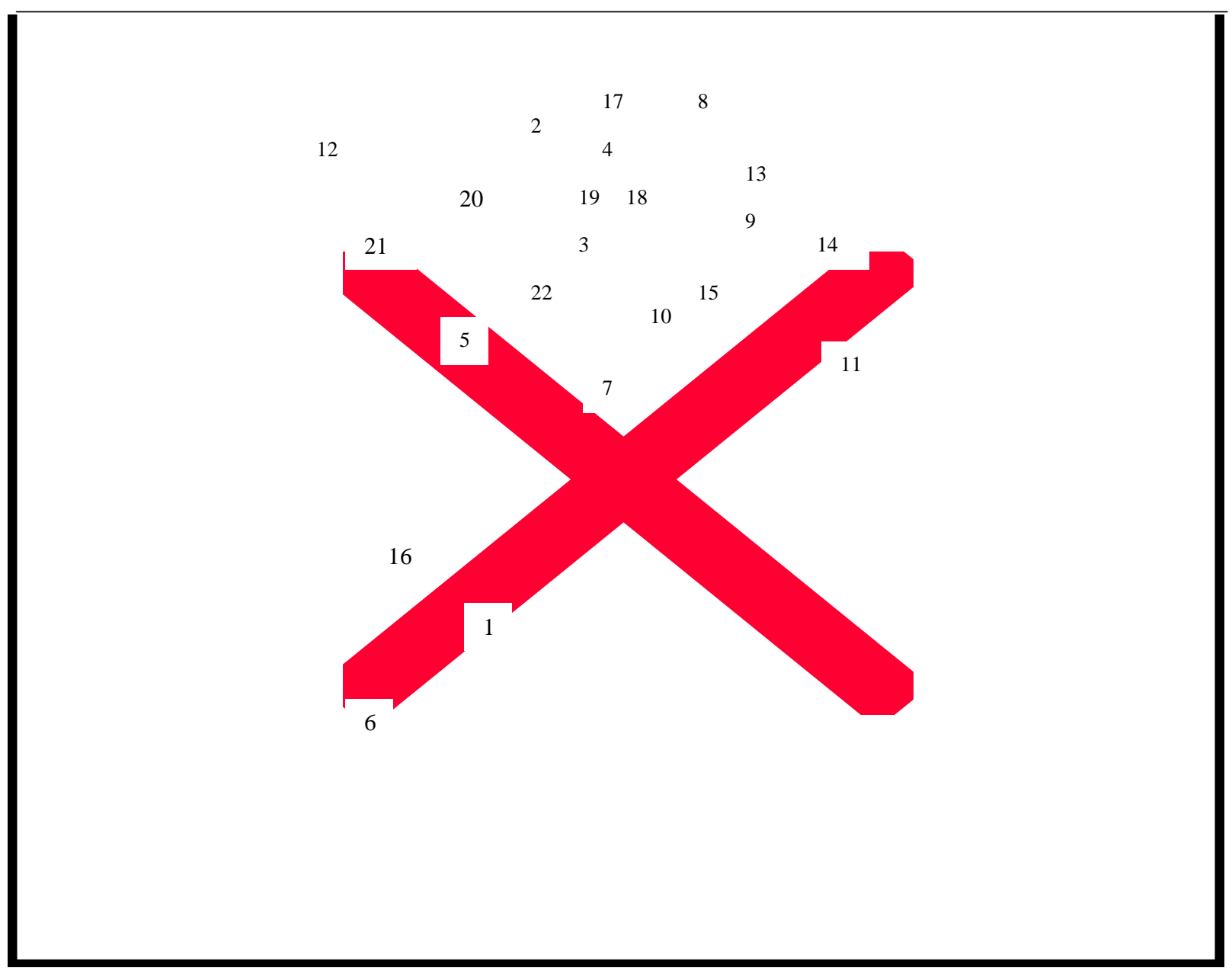

TABLE 3 Correlations of Performance, Satisfaction and Purchase Intentions

\begin{tabular}{|l|c|c|c|c||}
\hline & SERVPERF & S/Quality & Satisfaction & Intention \\
\hline \hline SERVPERF & 1.0000 & & & \\
\hline \hline Service Quality & $.6738^{*}$ & 1.0000 & & \\
\hline Satisfaction Level & $.7147^{*}$ & $.8022^{*}$ & 1.0000 & \\
\hline \hline Purchase Intention & $.2405^{*}$ & $.3445^{*}$ & $.3890^{*}$ & 1.0000 \\
\hline * Significant at .01 & & \\
\hline
\end{tabular}




\section{References}

1. Amsden, S. (1989), "Hitting the Service Excellence Target”, Industrial Management, Vol. 31, January/February, pp. 611 .

2. Anderson, C. and Zeithaml C.P. (1984) "Stage of the Product Life Cycle, Business Strategy, and Business Performance", Academy of Management Journal, Vol. 27, March, pp. 5-24.

3. Anderson, J. C. and Gerbing D. W. (1988), "Structural Equation Modeling in Practice: A Review and Recommendation Two-Step Approach", Psychological Bulletin, 103 (3), pp. 411-423.

4. Armstrong, S. J. and Overton, T. S. (1977), "Estimating Nonresponse Bias in Mail Surveys", Journal of Marketing Research, Vol. 14, August, pp.396-402.

5. Babakus, E. and Boller, G. W. (1992), "A Empirical Assessment of the SERVQUAL Scale”, Journal of Business Research, Vol. 24, pp. 253-268.

6. Babakus, E. and Mangold G. W. (1992), "Adapting the SERVQUAL Scale to Hospital Services: An Empirical Investigation", Health Service Research, 26 (6), pp. 767-780.

7. Badrick, T.C., Preston, A.P. and Saunders, I. (1997), "Evaluating Total Quality Management in Health-Care Organisations Using a Logical Model”, Asia Pacific Journal of Quality Management, 4(3), pp. 30-43.

8. Bagozzi, R.P. and Yi, Y. (1988), "On the Evaluation of Structural Equation Models", Journal of the Academy of Marketing Science, Vol. 16, Spring, pp. 74- 94.

9. Beach, L.R. and Burns, L.R. (1995), "The service quality improvements strategy: Identifying priorities for change", International Journal of Service Industry Management, 7(2), pp. 3-15

10. Behara, R.S. and Lemmink, J. (1991), "Q-Matrix: A Multidimensional Approach to Using Service Quality Measurements", Proceedings of the EIASM Workshop on Quality Management in Services, Strategic Quality Management Institute, The Netherlands, pp. 55-65

11. Berry, L.L. (1986), "Big Ideas in Services Marketing”, in Venkatesan, M., Schmalensee, D.M. and Marshall, C. (Eds), Creativity in Services Marketing, American Marketing Association, Chicago, IL, pp. 6-8.

12. Bitner, M.J., Booms, B. and Tetreault, M. (1990), “The Service Encounter: Diagnosing Favourable and Unfavourable Incidents", Journal of Marketing, Vol. 54, January, pp. 50-65.

13. Bolton, R. N. and Drew, J. H.(1991 a), "A Longitudinal Analysis of the Impact of Service Changes on Customer Attitudes", Journal of Marketing, Vol. 55, January, pp. 1-9.

14. Bolton, R N. and Drew J. H. (1991 b), “A Multistage Model of Customers' Assessments of Service Quality and Value”, Journal of Consumer Research, Vol. 17, March, pp. 375-384.

15. Bopp, K. D. (1990), "How Patients Evaluate the Quality of Ambulatory Medical Encounters: A Marketing Perspective", Journal of Health Care Marketing, Vol. 10, March, pp. 6-15.

16. Boulding, W., Kalra, A., Staelin, R. and Zeithaml, V. A. (1993), “A Dynamic Process Model of Service Quality: From Expectations to Behavioral Intentions”, Journal of Marketing Research, Vol. 30, February 1993, pp. 7-27.

17. Brandt, D.R. and Reffett, K.L. (1989), "Focusing on Customer Problems to Improve Service Quality", in Bitner, M.J. and Crosby, L.A. (Eds), Designing a Winning Service Strategy, Proceedings, American Marketing Association.

18. Carman, J. M. (1990), "Consumer Perceptions of Service Quality: An Assessment of the SERVQUAL Dimensions", Journal of Retailing, 66 (1), pp. 33-55.

19. Chang, Z.Y., Yeong, W.Y. and Loh L. (1997), “Critical Success Factors for Inflight Catering Services: Singapore Airport Terminal Services' Practices and Management Benchmarks", The TQM Magazine, 9(4), pp. 255-259.

20. Churchill, G. A. Jr. (1979), “A Paradigm for Developing Better Measures of Marketing Constructs”, Journal of Marketing Research, Vol. 16, February, pp. 64-73.

21. Churchill, G. A. Jr., Brown, T. J. and Peter J. P. (1993), "Improving the Measurement of Service Quality", Journal of Retailing, 69 (1) Spring, pp. 127139.

22. Cronin J. J. Jr. and Taylor, S. A. (1992), "Measuring Service Quality: A Re-examination and Extension", Journal of Marketing, Vol. 56, July, pp. 55-68.

23. Cronin, J. J. Jr. and Taylor, S. A. (1994), "SERVPERF Versus SERVQUAL: Reconciling Performance - Based and Perception - Minus - Expectations Measurement of Service Quality”, Journal of Marketing, Vol. 58, January, pp. 125131.

24. Darby, M. R. and Karni, E. (1973), "Free Competition and the Optimal Amount of Fraud", Journal of Law and Economics, Vol. 16, April, pp. 67-86.

25. Denton, D.K. (1990), “The Service Imperative”, Personnel Journal, Vol. 69, March, pp. 71-80.

26. Devlin, S. J. and Dong, H. K. (1994), "Service Quality From the Customer Perspective”, Marketing Research, 6 (1), Winter, pp. 5-13.

27. Donabedian, A. (1980), "The Definition of Quality and Approaches to Its Assessment", Explorations in Quality Assessment and Monitoring. Vol 1, Michigan: Health Administration Press, Ann Arbor. 
28. Donabedian, A. (1982), "The Criteria and Standards of Quality", Explorations in Quality Assessment and Monitoring, Vol 2, Michigan: Health Administration Press, Ann Arbor.

29. Gronroos, C. (1982), Strategic Management and Marketing in the Service Sector, Helsinki, Swedish School of Economics and Business Administration, Finland.

30. Gronroos, C. (1984), “A Service Quality Model and Its Marketing Implications”, European Journal of Marketing, Vol. 18 , pp. 36-44.

31. Hall, I.W. (1997), "Using ISO 9000 to Improve Customer Service", The TQM Magazine, 9(5), pp. 324-327.

32. Hawes, J. M. and Rao, C. P. (1985), "Using Importance-Performance Analysis to Develop Health Care Marketing Strategies", Journal of Health Care Marketing, Fall, pp. 19-25.

33. Hawes, J. M. and Glisan, G. (1983), “A Marketing Approach to Student Evaluation of a Department of Marketing”, in AMA Educators' Proceedings, Murphy, P.E. et. al. (Eds.), American Marketing Association, Chicago, pp. $159-163$.

34. Hawes, J. M., Kiser, G. E. and Rao, C. P. (1982), "Analyzing the Market for Planned Retirement Communities in the Southwest”, Baylor Business Studies, Vol. 13, August-October, pp. 39-46.

35. Henkoff, R. (1994), "Service Is Everybody's Business", Fortune, June 27, pp. 48-60.

36. Kettinger, W.J. and. Lee, C.C. (1997), "Pragmatic Perspective's on the Measurement of Information Systems Service Quality”, MIS Quarterly; 21 (2), pp. 223-240.

37. Kingman-Brundage, J. (1989), "The ABCs of Service System Blueprinting”, in Bitner, M.J. and Crosby, L.A. (Eds), Designing a Winning Service Strategy, Proceedings, American Marketing Association, Chicago, IL, pp. 30-33.

38. Knights, D. and McCabe, D. (1996), "A Bridge Too Far?: Consider Initiatives in Financial Services", The TQM Magazine, 8(5), pp. 51-55

39. Martilla, J. A. and James, J. C. (1977), "Importance-Performance Analysis", Journal of Marketing, Vol. 41, January, pp. 77-79.

40. Motwani, J., Kumar A. and Mohamed, M. (1996), "Implementing QFD for Improving Quality in Education: An Example”, Journal of Professional Service Marketing, 14 (2), pp. 25-34.

41. Nelson, P. (1974), “Advertising as Information”, Journal of Political Economy, Vol. 81, July/August, pp. $729-754$.

42. Oliver, R.L. (1993), “A Conceptual Model of Service Quality and Service Satisfaction: Compatible Goals, Different Concepts", in Advances in Services Marketing and Management Research and Practice, Vol. 2, Swartz, T.A., Bowen, D.E. and Brown, S.W. (Eds.), CT: JAI Press, Greenwich.

43. Parasuraman, A., Berry L. and Zeithaml, V. A. (1990), "An Empirical Examination of Relationships in an Extended Service Quality Model”, Working Paper Report No. 90-122, Marketing Service Institute, Cambridge, MA.

44. Parasuraman, A., Zeithaml, V. A. and Berry L. L. (1985), “A Conceptual Model of Service Quality and Its Implications for Future Research", Journal of Marketing, Vol. 49, Fall, pp. 41-50.

45. Parasuraman, A., Zeithaml, V. A. and Berry, L. L. (1988), "SERVQUAL: A Multiple-item Scale for Measuring Consumer Perceptions of Service Quality”, Journal of Retailing, Vol. 64, Spring, pp.12-40.

46. Parasuraman, A., Zeithaml, V. A. and Berry, L. L. (1991), "Refinement and Reassessment of the SERVQUAL Scale", Journal of Retailing, 67 (4), Winter, pp. 420-450.

47. Parasuraman, A., Zeithaml, V. A. and Berry, L. L. (1994), "Reassessment of Expectations as a Comparison Standard in Measuring Service Quality: Implications for Further Research", Journal of Marketing, Vol. 58, January, pp. 111-124.

48. Pheng, L.S. and Ke-Wei, P. (1996), “A Framework for Implementing TQM in Construction”, The TQM Magazine, 8(5), pp. 39-46.

49. Press, I. and Ganey, R. F. (1989), "The Mailout Questionnaire as the Practical Method of Choice in Patient Satisfaction Monitoring", Journal of Health Care Marketing, Vol. 9, March, pp. 67-68.

50. Sethna, B. N. (1982), "Extensions and Testing of Importance-Performance Analysis", in Kothan, V. (Ed.), Developments in Marketing Science, Vol. 5, Academy of Marketing Science, Nacogdoches, Texas, pp. $327-331$.

51. Sohal, A.S. and Lu, E. (1998), "The Quest for Quality in Safeway Australia", Asia Pacific Journal of Quality Management, 4(3), pp. 44-61.

52. Stauss, B. (1993), "Service Problem Deployment: Transformation of Problem Information into Problem Prevention Activities”, International Journal of Service Industry Management, 4(2), pp. 41-62.

53. Teas, K. R. (1993), "Consumer Expectations and the Measurement of Perceived Service Quality", Journal of Professional Services Marketing, 8 (2), pp. 18-21.

54. Witt, C. A. and Stewart, H. M. (1996), "Solicitors and Customer Care", The Service Industries Journal, 16(1), pp. 2132.

55. Zeithaml, V. A., Berry, L. L. and Parasuraman, A. (1990), Delivering Service Quality: Balancing Customer Perceptions and Expectations, The Free Press, New York. 
Notes 